\title{
PENGEMBANGAN MEDIA VIDEO ANIMASI BERBASIS PLOTAGON DAN KINEMASTER DALAM MENINGKATKAN MINAT BELAJAR SISWA SD
}

\author{
${ }^{1}$ Tantina Mindrianingsih, ${ }^{2}$ Yulia Eka Yanti \\ ${ }^{1}$ SDN 3 Babadan Ngajum, ${ }^{2}$ PGSD FIP Universitas Islam Raden Rahmat, \\ 1 tytaniajasmine@gmail.com \\ 2 yuliaekay@gmail.com
}

\begin{abstract}
This research is motivated by the low interest in learning of students in theme 7 class II subjects at SD Negeri 3 Babadan. The objectives of this study are: 1) To determine the validity of Plotagon and Kinemaster based animated video media in learning Theme 7 Sub-theme 2 learning 3,2) To determine the feasibility of Plotagon and Kinemaster based animated video media in the material for Theme 7 Subtheme 2 learning 3,3) To increase the learning interest of grade II student at SD Negeri 3 Babadan. The type of research used is qualitative research using the Research and Development (R\&D) method referring to the ADDIE. In collecting data the researchers used the necessary research instruments including observation, filling out questionnaires and documentation. The result showed that the Plotagon and Kinemaster based animated video media, is valid and feasible as a learning medium with revisions based on suggestions from material and media experts. The learning interest of students before using animated video media was very low, the total score was 1093.75 with an average 54.68 classical completeness reached $20 \%$. After using animated video media, there was a significant increase, the total score increased 1882.25 with an average of 94.11 classical completeness of $100 \%$. It can be said that Plotagon and Kinemaster based animated video media are valid and feasible to use increasing students interest in learning.
\end{abstract}

Keyword: Media Plotagon, Kinemaster, Interest in Learning

\section{ABSTRAK}

Penelitian ini dilatarbelakangi oleh rendahnya minat belajar peserta didik pada mata pelajaran tema 7 kelas II SD Negeri 3 Babadan. Tujuan dari penelitian ini yaitu: 1) Untuk mengetahui kevalidan media video animasi bebasis Plotagon dan Kinemaster dalam pembelajaran Tema 7 Subtema 2 Pembelajaran 3, 2) Untuk mengetahui kelayakan media video animasi berbasis Plotagon dan Kinemaster dalam materi Tema 7 Subtema 2 Pembelajaran 3, 3) Untuk meningkatkan minat belajar siswa kelas II di SD Negeri 3 Babadan. Jenis penelitian yang digunakan adalah penelitian kualitatif menggunakan metode Research and Development (R\&D) mengacu pada model ADDIE. Dalam mengumpulkan data peneliti menggunakan instrument penelitian yang diperlukan meliputi: observasi, pengisian angket dan dokumentasi. Hasil penelitian menunjukkan bahwa media video animasi berbasis Plotagon dan Kinemaster valid dan layak sebagai media pembelajaran dengan revisi berdasarkan saran para ahli materi dan media. Minat belajar peserta didik sebelum menggunakan media video animasi sangat rendah total skor keseluruhan 1093,75 dengan rata-rata 54,68 ketuntasan klasikal mencapai $20 \%$. 
Setelah menggunakan media video animasi mengalami peningkatan yang cukup signifikan, total skor keseluruhan meningkat mejadi 1882,25 rata-rata 94,11 ketuntasan klasikal $100 \%$. Hal ini dapat dikatakan bahwa media video animasi berbasis Plotagon dan Kinemaster valid dan layak digunakan dalam meningkatkan minat belajar peserta didik.

Kata Kunci: Media Plotagon, Kinemaster, Minat Belajar

\section{A. Pendahuluan}

Pendidikan diartikan dalam Kamus Besar Bahasa Indonesia (KBBI) berasal dari kata dasar didik (mendidik), yaitu: memelihara dan memberi latihan (ajaran, pimpinan) mengenai akhlak dan kecerdasan pikiran. Pendidikan menurut Tirtaraharjda dan Sulo (2014) adalah sesuatu yang universal dan berjalan terus menerus tanpa ada putusnya dari generasi ke generasi. Upaya memanusiakan manusia melalui pendidikan itu diselenggarakan sesuai dengan pandangan hidup dan dalam latar belakang sosial-kebudayaan setiap masyarakat tertentu. Penjelasan diatas dapat disimpulkan bahwa pendidikan adalah usaha seseorang dalam memanusiakan manusia dengan cara memelihara, memberi latihan mengenai akhlak dan kecerdasannya.

Pendidikan merupakan usaha sadar antara pendidik dan peserta didik dalam hal untuk membentuk dan mengembangkan perilaku, sikap, pengetahuan, keterampilan, dan potensi yang ada pada diri seseorang.

Menurut Kemendikbud (2020) menteri pendidikan Nadhiem Makarim pada tanggal 24 Maret 2020 mengeluarkan surat Edaran Nomor 4 Tahun 2020 tentang pelaksanaan kebijakan pendidikan dalam masa darurat penyebaran virus corona (Covid-19). Krisis benar-benar datang secar tiba-tiba, pemerintah di belahan bumi manapun termasuk Indonesia harus mengambil keputusan yang pahit menutup sekolah. Di Indonesia banyak keluarga yang kurang familier untuk melakukan sekolah di rumah. Bersekolah di rumah bagi keluarga Indonesia adalah kejutan besar khususnya bagi produktivitas orang tua yang biasanya sibuk dengan pekerjaannya di luar rumah. Demikian juga dengan problem psikologis peserta didik yang terbiasa belajar bertatap muka langsung dengan pendidik mereka. Seluruh elemen pendidikan secara kehidupan sosial "terpapar" sakit karena Covid-19. Pelaksanaan pengajaran berlangsung secara online. Pendidik perlu mengembangkan media pembelajaran digital yang menarik, efektif, dan efisien, dan mudah diakses oleh peserta didik di manapun berada.

Pembelajaran tidak akan berjalan dengan lancar tanpa adanya faktor pendukung, salah satunya faktor tersebut adalah media yang digunakan. Pendidik bukanlah satusatunya sumber informasi bagi kegiatan belajar peserta didik, karena peran pendidik saat ini adalah sebagai fasilitator. Pendidik harus lebih kreatif dan inovatif dalam mengajar, pendidik juga harus mumpuni dalam menggunakan media pembelajaran yang akan digunakan. Hal ini dipertegas oleh Arsyad (2013) bahwa media merupakan sebuah jembatan pengantar bagi pendidik dan peserta didik untuk mendapatkan ilmu pengetahuan. Media merupakan alat yang digunakan pendidik untuk menyampaikan pesan yang berisi materi pembelajaran kepada peserta 
didik agar mudah dipahami. Hal ini meminimalisir para peserta didik yang enggan dan kurang adanya minat dalam mengikuti kegiatan belajarmengajar secara digital.

Berdasarkan hasil observasi yang telah dilakukan oleh peneliti pada bulan Agustus sampai September di SD Negeri 3 Babadan, ditemukan masalah bahwa; (a) metode yang digunakan di kelas II SD Negeri 3 Babadan saat pembelajaran adalah menggunakan metode ceramah dan diskusi; (b) sedikitnya media pembelajaran yang dimiliki oleh lembaga sekolah; (c) kurang menariknya media pembelajaran yang digunakan oleh pendidik, Hal ini karena pendidik hanya menggunakan LKS, buku cetak, media gambar, dan papan tulis, saat menerangkan materi; (d) penggunaan model pembelajaran secara konvensional ini membuat peserta didik menjadi pasif, sehingga mengakibatkan kurang keaktifan dan rendahnya minat dalam belajar; (e) peserta didik kurang memperhatikan saat pendidik menjelaskan, ada yang mengobrol dengan teman sebangkunya, ada juga yang bermain sendiri, ini menandakan bahwa minat peserta didik saat pembelajaran sangat rendah.

Mengacu pada hasil observasi tersebut, maka peneliti akan mengembangkan sebuah media pembelajaran berbasis video animasi. Menurut Putri (2016) bahwa dengan menggunakan media animasi dapat meningkatkan nilai peserta didik yang sebelum menggunakan media tersebut nilainya rendah. Media animasi ini memberikan kemudahan kepada peserta didik dalam memahami materi Bahasa Indonesia dalam hal (mendengarkan, membaca, berbicara, menulis) dan ditunjukkan nilai para peserta didik di SDN Pendowoharjo meningkat. Permatasari dkk (2019) menyatakan bahwa media pembelajaran video animasi tangan bergerak dengan konteks lingkungan layak digunakan dan dapat memberikan pemahaman kepada siswa kelas IV tentang kegiatan ekonomi material berdasarkan potensi alam. Menurut Munir (2017) video animasi adalah merupakan pergerakan subjek atau gambar sehingga bisa berubah posisi letaknya, objek juga mengalami perubahan warna dan bentuknya sehingga peserta didik akan menyukai media tersebut, karena bermanfaat sebagai penunjang pembelajaran. Manfaat lain mengembangkan media pembelajaran dalam proses kegiatan belajar mengajar dapat membangkitkan minat belajar peserta didik. 
Minat diartikan sebagai kecenderungan hati yang tinggi, keinginan, sedangkan berminat diartikan mempunyai (menaruh) minat, kecenderungan hati, keinginan terhadap sesuatu. Menurut Kamus Besar Bahasa Indonesia (KBBI) minat adalah keinginan kecenderungan hati terhadap sesuatu. Sedangkan menurut Sujanto (2013) menyatakan minat adalah sesuatu pemusatan terhadap sesuatu yang tidak disengaja yang terlahir atas kemauanya yang tergantung dari bakat dan lingkungan. Disimpulkan bahwa minat adalah keinginan, ketertarikan dan keterlibatan seseorang untuk mempelajari sesuatu yang dirasa sangat penting bagi dirinya pribadi dengan perasaan senang.

Berdasarkan paparan diatas maka diambil sebuah penelitian dalam bentuk skripsi yang berjudul "Pengembangan Media Video Animasi Berbasis Plotagon dan Kinemaster Dalam Meningkatkan Minat Belajar Siswa Kelas II Di Sekolah Dasar".

\section{B. Metode Penelitian}

Penelitian ini merupakan jenis penelitian dan pengembangan Research and Development (R\&D). Metode pengembangan Research and Development (R\&D) merupakan metode penelitian yang digunakan untuk menghasilkan produk tertentu, dan digunakan untuk menguji keefektifan dari produk tersebut. Melalui penelitian dan pengembangan ini, peneliti berusaha untuk mengembangkan prouduk yang layak dan efektif digunakan dalam pembelajaran. Produk yang dikembangakan pada penelitian ini adalah media pembelajaran berupa video animasi yang memudahkan siswa untuk memahami pembelajaran di kelas II Sekolah Dasar.

Penelitian ini mengacu pada model ADDIE dengan menggunakan lima langkah pelaksanan. Model ADDIE dikembangankan oleh Dick and Carrey (1996). Menurut Sugiyono (2009) tahap-tahapnya dapat disebutkan sebagai berikut: (Analyze, Design, Development, Implementation, Evaluation). Tujuan awal dari penelitian R\&D ini adalah sebagai fungsi pengembangan, sedangkan tujuan kedua yaitu sebagai validasi. Dengan demikian konsep penelitian pengembangan lebih tepat diartikan sebagai upaya pengembangan yang disertai dengan upaya validasi. Langkah-langkah tersebut dijelaskan sebagai berikut:

1. Analisis

Tahap ini untuk mengetahui kebutuhan dalam mengembangkan media pembelajaran dengan menganalisis karakteristik peserta didik, kurikulum, materi, dan analisis media.

2. Perancangan

Tahap kedua ini peneliti membuat rancangan atau desain produk dari hasil analisis tahap sebelumnya.

3. Pengembangan

Pada tahap ini, pembuatan media berdasarkan storyboard dan flowchart yang telah dibuat.

4. Implementasi Implementasi merupakan tahap yang dilakukan setelah

$$
\begin{array}{|l}
=\frac{\sum \text { Nilai }}{\sum \text { skor yang diperoleh siswa }} \\
\text { media pembelajaran direvisi } \\
\text { dengan baik yaitu di } \\
\text { implmentasikan kepada peserta } \\
\text { didik. }
\end{array}
$$

5. Evaluasi 
Pengelolaan data penilaian dilakukan dengan mendeskripsikan semua pendapat, saran, dan tanggapan dari validator.

Pengumpulan data pada penelitian ini menggunakan instrumen antara lain: 1) Dokumentasi didapatkan saat melakukan penelitian, 2) Angket dalam penelitian ini berupa angket minat belajar yang akan diberikan

\begin{tabular}{|c|c|}
\hline Skor & Keterangan \\
\hline 5 & Sangat Baik \\
\hline 4 & Baik \\
\hline 3 & Cukup Baik \\
\hline $\begin{array}{l}\text { Nilai2 } \\
=\sum \text { skor }\end{array}$ & $\begin{array}{c}\text { Kurang } \\
\text { kitfurgagekaldo }\end{array}$ \\
\hline \multicolumn{2}{|c|}{$=\frac{\sum \text { skor kriterium }}{1}$} \\
\hline \multicolumn{2}{|c|}{$\begin{array}{l}\text { sebanyak dua kali yaitu sebelum } \\
\text { menggunakan media video animasi } \\
\text { dan sesudah menggunakan media }\end{array}$} \\
\hline $\begin{array}{l}\text { video } \\
\text { menggu } \\
\text { seperti p }\end{array}$ & $\begin{array}{l}\text { asi. Dengan } \\
\text { esain Before-After } \\
\text { hbar } 1 \text { berikut ini: }\end{array}$ \\
\hline
\end{tabular}

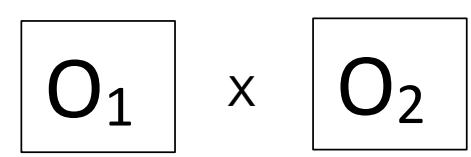

Gambar 1. Desain (before-after)

Sugiyono (2017)

Angket respon peserta didik terkait kelayakan dan keterbacaan media menggunakan skala Guttman dengan rumus sebagai berikut.

Setelah diperoleh skor dapat dikategori sebagai berikut:

Tabel 1. Skala Minat

Sumber: Herawan (2012)

Berikut ini rumus yang digunakan untuk menghitung kelayakan produk media (keterbacaan dan kemenarikan) dari jawaban peserta didik.

Data yang diperoleh dari respon peserta didik melalui angket keterbacaan dan kemenarikan dapat ditentukan tingkat kelayakan produk berdasarkan presentase dengan kualifikasi kriteria sebagai berikut:

Tabel 2. Kualifikasi Tingkat Kelayakan Media

\begin{tabular}{|c|c|c|}
\hline $\begin{array}{c}\text { Presentase } \\
(\%)\end{array}$ & $\begin{array}{c}\text { Kriteria } \\
\text { Kelayakan }\end{array}$ & Keterangan \\
\hline$P \geq 90 \%$ & $\begin{array}{c}\text { Sangat } \\
\text { baik }\end{array}$ & $\begin{array}{l}\text { Sangat } \\
\text { layak }\end{array}$ \\
\hline $\begin{array}{c}80 \% \leq p \\
90 \%\end{array}$ & Baik & Layak \\
\hline $\begin{array}{c}70 \% \leq p< \\
80 \%\end{array}$ & Cukup & Cukup layak \\
\hline$P<60 \%$ & Kurang & $\begin{array}{l}\text { Kurang } \\
\text { layak }\end{array}$ \\
\hline
\end{tabular}

Sedangkan Berikut ini rumus yang digunakan untuk menghitung kelayakan produk media berdasarkan skor penilaian yang diberikan oleh validator.

Nilai yang diperoleh para ahli dapat ditentukan dengan kualifikasi kriteria sebagai berikut:

Tabel 3. Kategori Skor Skala Likert Sumber: Sugiyono (2015)

Data yang diperoleh dari para validator dapat ditentukan tingkat kelayakan produk berdasarkan presentase dengan kualifikasi kriteria sebagai berikut:

Tabel 4. Kriteria Interpretasi Skor

$=\frac{\sum \text { skor yang diperoleh siswa }}{\sum \text { skor maksimum }} \times 100$

\begin{tabular}{c|c}
\hline Perolehan Skor & Kategori \\
\hline$\geq 80$ keatas & Tinggi \\
$60-79$ & Sedang \\
$\leq 59$ & Rendah \\
\hline
\end{tabular}


Sumber: Adopsi Riduan (2012)

\section{Hasil Penelitian dan Pembahasan}

Pengembangan media video animasi berbasis plotagon dan kinemaster dikembangan dengan menggunakan model ADDIE, tahapan-tahapan model ADDIE adalah: Analisis, Perancangan, Pengembangan, Penerapan, dan Evaluasi. Berikut ini penjelasan terkait model ADDIE pada penelitian.

1. Analisis

Pada tahap analisis, kegiatan awal sebelum melakukan pengembangan produk terhadap media video animasi ini adalah analisis kurikulum, materi, karakteristik siswa dan analisis kebutuhan. Analisis kebutuhan diawali dengan melakukan observasi di SD Negeri 3 Babadan. Hasil yang diperoleh peneliti saat melakukan observasi yaitu kurangnya minat belajar peserta didik pada materi

\begin{tabular}{ccc}
\hline Presentase & Kualifikasi & Keterangan \\
\hline $81 \leq p<$ & Sangat & Tidak Revisi \\
100 & valid & \\
$61 \leq p<80$ & Valid & Tidak Revisi \\
$41 \leq p<60$ & Cukup & Revisi \\
& valid & Sebagian \\
$21 \leq p<40$ & $\begin{array}{c}\text { Kurang } \\
\text { valid }\end{array}$ & Revisi \\
& Tidak valid & Revisi \\
$0 \leq p<20$ & Tidal
\end{tabular}

Tema 7 St $2 \mathrm{~Pb} 3$. Salah satu tanda dari hal tersebut adalah kurang semangat peserta didik saat pendidik memberikan materi pembelajaran, mereka banyak yang mengobrol dengan teman sebangkunya saat pembelajaran berlangsung. Selain kedua hal tersebut diketahui guru hanya menggunakan media papan tulis dan buku LKS, terkadang menggunakan media LCD proyektor dan gambar.

Menanggapi hal tersebut diperlukan media pembelajaran yang tepat untuk menyampaikan materi. Media yang dapat membantu peserta didik berpikir logis dengan bantuan contoh nyata. Media yang sesuai untuk memenuhi kebutuhan tersebut adalah media video animasi, media video animasi dapat mengembangkan dan meningkatkan minat peserta didik. Oleh karena itu perlu adanya pengembangan video animasi yang dapat membantu proses pembelajaran agar peserta didik lebih mudah dan lebih berminat untuk memahami materi yang sedang diajarkan.

\section{Perancangan}

Tahap kedua pada penelitian ini adalah tahap perancangan media video animasi pembelajaran dan perancangan alur navigasi pada media. Pada tahap ini perancangan media disesuikan dengan $\mathrm{KI}, \mathrm{KD}$, Indikator dan karakteristik peserta didik. Langkah-langkah yang dilakukan adalah: 1) menyusun kebutuhan media video animasi yaitu dengan menentukan $\mathrm{KD}, \mathrm{KI}$, dan Indikator. Mengumpulkan alat dan bahan yang dibutuhkan. Mengumpulkan gambar yang digunakan. Menyiapkan perangkat pembelajaran. 2) mendesain media video animasi yang terdiri dari desain cover media. Pada rancangan desain cover media video animasi ini peneliti mengacu dan melihat berbagai tutorial pembuatan cover pada youtube, agar menghasilkan cover yang baik dan menarik yang terdapat pada gambar berikut ini.

Tabel 5. Cover Media

\begin{tabular}{|c|c|}
\hline Tampilan & Keterangan \\
\hline & Cover Media \\
\hline
\end{tabular}

Pada rancangan isi dari media video animasi dibuat dengan 
mengaplikasikan berbagai macam gambar disetiap materi yang akan dibahas. Peneliti menggunakan gambar yang bisa menarik perhatian peserta didik. Peneliti juga menggunakan warna dan kontras yang sesuai agar isi dari media tersebut disukai dan mudah dipahami oleh peserta didik yang terdapat pada Gambar 6 berikut ini:

Tabel 6. Tampilan Isi Media

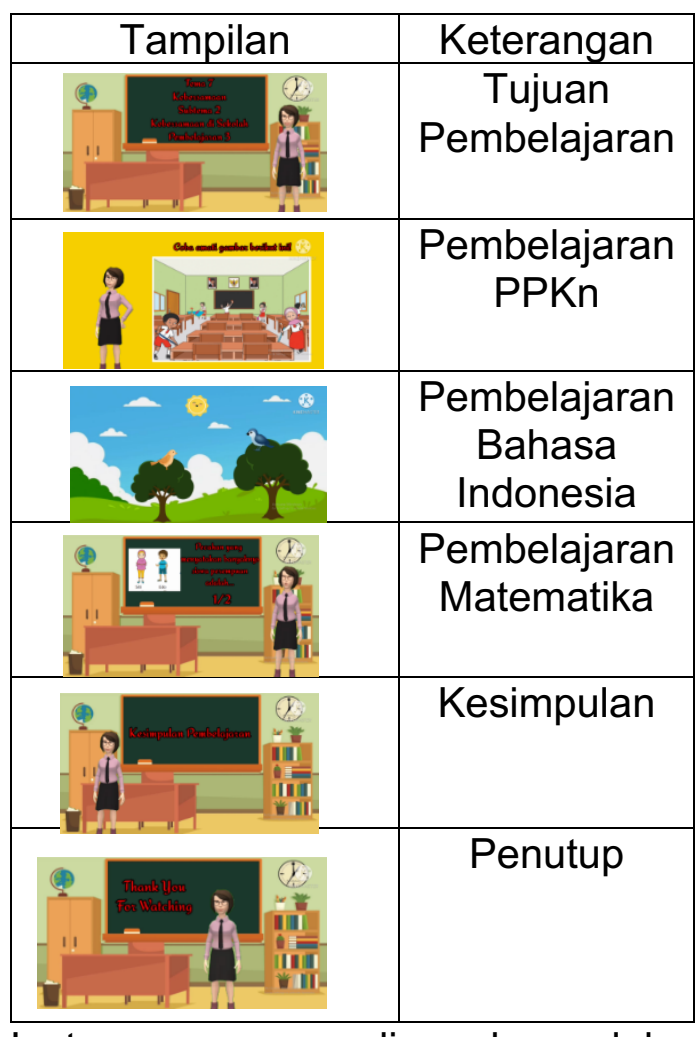

Instrumen yang digunakan dalam penelitian ini yaitu meliputi: validasi ahli materi, validasi ahli media, angket minat belajar, angket keterbacaan, dan angket kemenarikan.

a. Lembar validasi ahli materi

Lembar validasi ahli materi diberikan kepada ahli materi, dengan penilaian validasi dapat diketahui kevalidan materi pada media video animasi. Aspek penilaian ahli materi meliputi tiga aspek yaitu aspek relevansi silabus dengan tujuan pembelajaran, kualitas materi, dan Bahasa tipografi. Terdapat 8 butir pernyataan dengan total skor 40 . b. Lembar validasi ahli media

Lembar validasi ahli media diberikan kepada ahli media, dengan penilaian validasi dapat diketahui kevalidan media pada media video animasi. Aspek penilaian ahli materi meliputi enam aspek yaitu aspek fungsi dan manfaat, visual media, audio media, tipografi, Bahasa, dan pemrograman media. Terdapat 15 butir pernyataan dengan total skor 75 . c. Angket respon peserta didik

Angket respon diberikan kepada peserta didik untuk mengetahui tanggapan terkait media video animasi ini. Angket respon diberikan sebelum dan sesudah menggunakan media video animasi. Angket respon disusun berdasarkan empat indikator yang akan dicapai meliputi: perasaan senang, perhatian, ketertarikan, dan keterlibatan peserta didik.

d. Angket keterbacaan

Angket keterbacaan diberikan kepada peserta didik untuk digunakan mengetahui tanggapan terkait media yang telah dibuat dapat terbaca oleh peserta didik atau belum. Angket keterbacaan terdiri dari 12 butir pertanyaan.

\section{e. Angket kemenarikan}

Angket kemenarikan diberkan kepada peserta didik kelas II untuk digunakan mengetahui tanggapan terkait media yang telah dibuat dapat membuat peserta didik tertarik apa tidak. Angket kemenarikan terdiri dari 15 butir pertanyaan.

3. Tahap

Pengembangan

(Development)

Pada tahap ini peneliti memulai membuat media sesuai dengan rancangan yang telah dilakukan. Selanjutnya membuat media video animasi, media di validasi oleh ahli materi dan ahli media dengan menggunkan angket yang telah 
disediakan oleh peneliti. Hasil validasi dari validator berupa saran dan komentar yang digunakan untuk merevisi media yang telah dibuat. Dimulai dengan mempersiapkan bahan-bahan yang digunakan untuk membuat video animasi seperti: a). Handphone, b). Aplikasi Plotagon, c). Aplikasi Kinemaster, d). Gambargambar format PNG.

Setelah bahan-bahan sudah siap maka tahap selanjutnya adalah memproduksi media pembelajaran berupa video animasi. Persiapan dimulai dengan mengkoneksikan handphone dengan jaringan internet (Wi-Fi) kemudian masuk pada aplikasi plotagon dan kinemaster.

\section{a) Aplikasi Plotagon}

Pada tahap ini yang dilakukan pertama kali adalah membuat video baru dengan memilih background terlebih dahulu pilih create video. Masukkan karakter yang akan digunakan dengan cara klik create character, pilih male untuk membuat karakter berjenis kelamin laki-laki dan female untuk karakter berjenis kelamin perempuan. Ubah sedemikian rupa mulai dari warna kulit, model rambut, asesoris, sepatu, baju dll. Jika ingin mengubah ekspresi pada tokoh maka klik tombol Neutral untuk mengganti dan memilih berbagai macam ekspresi yang sesuai.

Properti dan setting background disesuaikan dengan ide cerita untuk menunjang tercapainya alur cerita. Setelah background, tokoh, dan properti selesai dipilih, langkah selanjutnya adalah membuat rekaman suara. Pada proses rekaman suara peneliti memilih tempat yang sepi dan sunyi agar kualitas audio bersih dan jernih. Peneliti merekam audio secara terpisah di setiap scene. Masingmasing scene tidak bisa melebihi kurang lebih 20 detik. Tahap selanjutnya menyimpan video yang telah selesai dengan cara render video, tunggu beberapa menit, simpan pada gallery, berikan judul.

\section{b) Aplikasi Kinemaster}

Pada tahap ini dilakukan produksi yang dimulai dengan membuka aplikasi Kinemaster tekan tombol buat baru pada pojok kanan atas, pada menu Rasio Aspek pilih ukuran 16:9, klik berikutnya pada tombol pojok kanan atas. Pada layer pertama klik tanda media untuk pemilihan latar belakang. Background dapat dipilih atau diambil dari Gallery. Pada layer kedua klik lapisan yang didalamnya akan ada pilihan media. Media bisa berupa video atau gambar yang sudah siap di Gallery kemudian dapat diatur letak, ukuran, warna dan animasi masuknya. Jika yang dipilih video greenscreen, untuk menghilangkan warna hijau pada video greenscreen, klik video greenscreen pilih menu kunci kroma kemudian aktifkan dan atur hingga background hijau hilang dan bersih, bila sudah selesai klik centang pada pojok kanan atas.

Untuk membuat tulisan bisa klik teks kemudian diketik dan diatur bentuk, ukuran, warna dan animasi masuk dan keluarnya.. Untuk menambah rekaman suara dapat diklik tanda mic. Untuk Audio juga bisa ditambahkan sesuai dengan keinginan. Setelah semua selesai file bisa diekspor menjadi bentuk satu kesatuan video dengan cara mengklik pada lajur kiri dengan pilihan tombol share. Kemudian pilih kualitas gambar dengan resolusi FHD 1080p dengan frame 24 (Cinema) dan laju 16.11 Mbps. Kemudian klik ekspor dan ditunggu sampai selesai. Cek hasilnya di Gallery.

4. Implementasi (Implementation) Pada tahap ini peneliti menggunakan media video animasi 
untuk melakukan uji coba pada kelompok kecil dan kelompok terbatas, yang di implementasikan di SD Negeri 3 Babadan pada tanggal 2 Juni 2021. Peneliti membagikan angket respon sebanyak dua kali, sebelum menggunakan media dan sesudah menggunkan media sebagai landasan dalam mengukur minat belajar peserta didik. Kemudian peneliti memberikan angket keterbacaan kepada kelompok kecil, dan angket kemenarikan diberikan kepada kelompok terbatas.

5. Evaluasi (Evalution)

Tahap evaluasi merupakan tahap akhir yang dilakukan untuk mengevaluasi produk yang dikembangkan. Penelitian ini proses evaluasi dilaksanakan dengan cara melakukan klarifikasi terhadap perubahan minat pada pembelajaran yang sedang berlangsung. Hal ini dilakukan karena penelitian ini berfokus pada peningkatan minat belajar peserta didik.

\section{Pembahasan}

Hasil uji coba produk diperoleh dari penilaian ahli materi dan ahli media terkait materi dan media apakah layak digunakan untuk peserta didik.

\section{Ahli materi}

Ahli materi dalam penelitian ini adalah guru SD Negeri 3 Babadan yaitu Ibu Liswati, S.Pd. Seorang ahli materi telah melihat dan mencoba video animasi pembelajaran berbasis Plotagon dan Kinemaster maka diperoleh total 40 dari total nilai maksimum 40 dengan presentase 100\%. Dapat disimpulkan bahwa materi tema 7 pembelajaran 2 subtema 3 menggunakan media video animasi masuk dalam kategori "sangat valid". Hal ini diperkuat dengan teori Daryanto (2010) bahwa materi yang terkandung didalamnya harus sesuai dengan kurikulum dan mengandung banyak manfaat. Ini dapat diartikan bahwa materi yang tersaji sudah jelas dan tepat sesuai dengan yang diajarkan.

2. Ahli media

Ahli media dalam penelitian ini adalah Ibu Tety Nur Cholifah, M.Pd dosen PGSD di Fakultas IImu Pendidikan Universitas Islam Raden Rahmat Malang. Seorang ahli media melihat dan mencoba media video animasi pembelajaran berbasis Plotagon dan Kinemaste. Berdasarkan hasil angket validasi diperoleh hasil total 75 dari total nilai maksimum 75 dengan presentase $100 \%$. Disimpulkan bahwa materi tema 7 pembelajaran 2 subtema 3 menggunakan media video animasi masuk dalam kategori "sangat valid". Hal ini diperkuat oleh teori Sudarma dkk (2015) bahwa penggunaan warna yang konsisten, serta sesuai dengan realitas yang akan menambah pengetahuan siswa itu sendiri terkait lingungkannya. Selain itu warna yang digunakan dalam suatu media memiliki dampak besar pada pemikiran serta ketertarikan peserta didik untuk belajar.

\section{Peserta Didik}

Uji coba produk untuk peserta didik dilakukan setelah melakukan validasi dari ahli materi dan ahli media. Uji coba produk dibedakan menjadi dua macam kelompok yaitu:

\section{a.Uji Kelompok Kecil}

Uji coba kelompok kecil dilakukan pada tanggal 2 Juni 2021 di SDN 3 Babadan. Subjek uji coba kelompok kecil sebanyak 6 peserta didik kelas III SDN 3 Babadan. Data hasil uji coba oleh kelompok kecil diperoleh dari hasil pengisian angket minat sebelum dan sesudah menggunakan media. Dapat dilihat pada Gambar 2 diagram berikut ini

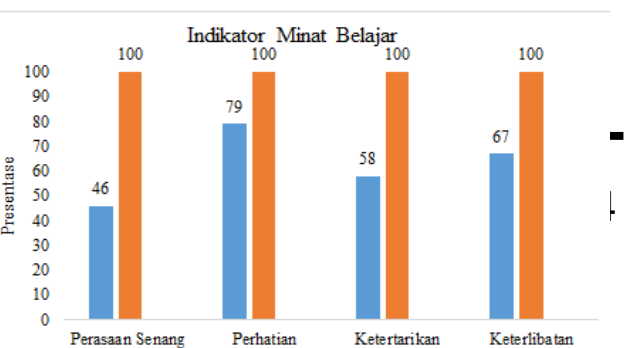




\section{Gambar 2. Diagram Minat Kelompok Kecil}

Dari hasil nilai indikator yang diperoleh diatas, maka dapat disimpulkan bahwa minat belajar peserta didik meningkat sesudah menggunakan media video animasi.

Rekapitulasi hasil pengisian angket minat belajar before dan after menggunakan media yang terdapat pada Tabel 7 sebagai berikut:

\section{Tabel 7. Before-After}

Berdasarkan hasil perlakuan (treatment) yang dilakukan menunjukkan bahwa hasil $\mathrm{O}_{2}$ lebih besar daripada $\mathrm{O}_{1}$, maka media pembelajaran dikatakan efektif dan layak diuji coba untuk kelompok,

\begin{tabular}{ccc}
\hline Before & Perlakuan & After \\
\hline 50 & $X$ & 94,11
\end{tabular}

disimpulkan kembali bahwa menggunakan media video animasi dapat meningkatkan minat belajar peserta didik pada Tema 7 materi Kebersamaan.

Angket keterbacaan diisi oleh peserta didik yang sudah pernah mengikuti kegiatan pembelajaran Tema 7 Subtema 2 Pembelajaran 3 yaitu siswa kelas III SD Negeri 3 Babadan yang berjumlah 6 orang. Peserta didik mengisi angket keterbacaan media sesudah menggunakan media video animasi. Hasil pengisian angket keterbacaan dapat di lihat Tabel 8 berikut ini.

\section{Tabel 8. Keterbacaan Media}

\section{b. Uji Kelompok Besar}

Uji coba kelompok terbatas dilakukan pada tanggal 2 Juni 2021

\begin{tabular}{|c|c|c|c|c|c|}
\hline $\mathrm{N}$ & $\begin{array}{c}\text { Aspe } \\
\mathrm{k} \\
\text { yang } \\
\text { dinila } \\
\mathrm{i}\end{array}$ & $\begin{array}{c}\text { Nil } \\
\text { ai }\end{array}$ & $\begin{array}{c}\text { Nil } \\
\text { ai } \\
\text { Ma } \\
x\end{array}$ & $\begin{array}{l}\text { Prese } \\
\text { ntase }\end{array}$ & $\begin{array}{c}\text { Kete } \\
\text { rang } \\
\text { an }\end{array}$ \\
\hline 1 & $\begin{array}{l}\text { Huru } \\
f\end{array}$ & $\begin{array}{l}16 \\
, 7\end{array}$ & $\begin{array}{c}16 \\
7\end{array}$ & $100 \%$ & $\begin{array}{c}\text { San } \\
\text { gat } \\
\text { baik }\end{array}$ \\
\hline 2 & $\begin{array}{l}\text { Baha } \\
\text { sa }\end{array}$ & $\begin{array}{l}33 \\
, 3\end{array}$ & $\begin{array}{c}33 \\
3\end{array}$ & $100 \%$ & $\begin{array}{c}\text { San } \\
\text { gat } \\
\text { baik }\end{array}$ \\
\hline 3 & $\begin{array}{l}\text { Kali } \\
\text { mat }\end{array}$ & 25 & 25 & $100 \%$ & $\begin{array}{c}\text { San } \\
\text { gat } \\
\text { baik }\end{array}$ \\
\hline 4 & $\begin{array}{l}\text { Ejaa } \\
n\end{array}$ & 25 & 25 & $100 \%$ & $\begin{array}{l}\text { San } \\
\text { gat } \\
\text { baik }\end{array}$ \\
\hline
\end{tabular}

di SDN 3 Babadan. Subjek uji coba kelompok terbatas sebanyak 20 peserta didik kelas II SDN 3 Babadan. Data hasil uji coba kelompok terbatas diperoleh hasil pengisian angket minat belajar dan angket kemenarikan. Dapat dilihat pada Gambar 3 berikut ini.

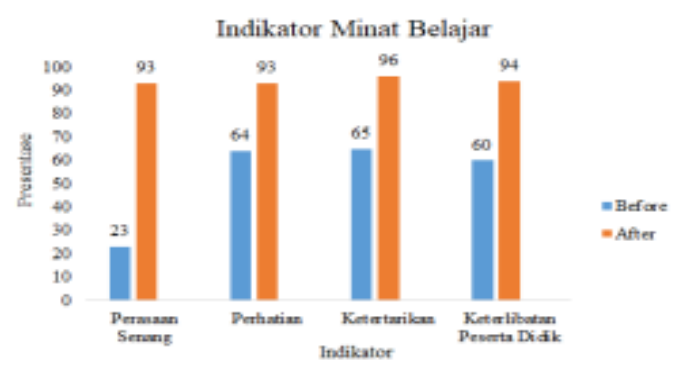

\section{Gambar 3. Diagram Minat Kelompok Terbatas}

Dari hasil nilai indikator yang diperoleh diatas, maka dapat disimpulkan bahwa minat belajar peserta didik meningkat sesudah 
menggunakan media video

\begin{tabular}{|c|c|c|c|c|c|}
\hline \multirow{2}{*}{\multicolumn{3}{|c|}{$\begin{array}{c}\text { Before } \\
54,68 \\
\end{array}$}} & \multirow{2}{*}{\multicolumn{2}{|c|}{$\frac{\text { Perlakuan }}{X}$}} & \multirow{2}{*}{$\begin{array}{c}\text { After } \\
100 \\
\end{array}$} \\
\hline & & & & & \\
\hline & Aspe & & & & \\
\hline $\begin{array}{l}\mathbf{N} \\
\mathbf{O}\end{array}$ & $\begin{array}{c}\mathbf{k} \\
\text { yang } \\
\text { Dinil } \\
\text { ai }\end{array}$ & $\begin{array}{l}\mathrm{Ni} \\
\text { lai }\end{array}$ & $\begin{array}{c}\mathrm{Ni} \\
\mathrm{Ma} \\
\mathrm{x}\end{array}$ & $\begin{array}{l}\text { Pre } \\
\text { sent } \\
\text { ase }\end{array}$ & $\begin{array}{c}\text { Keter } \\
\text { anga } \\
\text { n }\end{array}$ \\
\hline 1 & $\begin{array}{c}\text { Kem } \\
\text { enari } \\
\text { kan }\end{array}$ & $\begin{array}{l}33 \\
, 3\end{array}$ & $\begin{array}{c}26 \\
7\end{array}$ & $\begin{array}{c}100 \\
\%\end{array}$ & $\begin{array}{c}\text { Sang } \\
\text { at } \\
\text { Baik }\end{array}$ \\
\hline 2 & $\begin{array}{l}\text { Resp } \\
\text { on } \\
\text { sisw } \\
\text { a }\end{array}$ & $\begin{array}{c}13 \\
3\end{array}$ & 20 & $\begin{array}{c}100 \\
\%\end{array}$ & $\begin{array}{c}\text { Sang } \\
\text { at } \\
\text { Baik }\end{array}$ \\
\hline 3 & $\begin{array}{c}\text { Keak } \\
\text { tifan } \\
\text { sisw } \\
\text { a }\end{array}$ & $\begin{array}{l}13 \\
, 3\end{array}$ & $\begin{array}{c}13 \\
3\end{array}$ & $\begin{array}{c}100 \\
\%\end{array}$ & $\begin{array}{c}\text { Sang } \\
\text { at } \\
\text { Baik }\end{array}$ \\
\hline 4 & $\begin{array}{c}\text { Motiv } \\
\text { asi }\end{array}$ & $\begin{array}{l}13 \\
, 3\end{array}$ & $\begin{array}{c}13 \\
3\end{array}$ & $\begin{array}{c}100 \\
\%\end{array}$ & $\begin{array}{l}\text { Sang } \\
\text { at } \\
\text { Baik }\end{array}$ \\
\hline 5 & $\begin{array}{l}\text { Kejel } \\
\text { asan }\end{array}$ & 20 & 20 & $\begin{array}{c}100 \\
\%\end{array}$ & $\begin{array}{c}\text { Sang } \\
\text { at } \\
\text { Baik }\end{array}$ \\
\hline
\end{tabular}

animasi.

Rekapitulasi hasil pengisian angket minat belajar before dan after menggunakan media yang terdapat pada Tabel 9 sebagai berikut:

\section{Tabel 9. Before-After}

Data diatas menunjukkan bahwa hasil $\mathrm{O}_{2}$ lebih besar daripada $\mathrm{O}_{1}$, maka media pembelajaran dikatakan efektif dan layak diuji coba untuk kelompok, disimpulkan kembali bahwa menggunakan media video animasi dapat meningkatkan minat belajar peserta didik pada Tema 7 materi Kebersamaan.

$$
\text { Angket kemenarikan }
$$

diberikan kepada peserta didik kelas II SD Negeri 3 Babadan yang berjumlah 20 peserta didik. Peserta didik mengisi angket kemenarikan setelah menggunakan media video animasi. Hasil pengisian angket kemenarikan dapat dilihat pada Tabel 10 berikut ini.

\section{Tabel 10. Kemenarikan Media}

4. Media dapat meningkatkan minat belajar peserta didik

Pada dasarnya media adalah sebagai alat komunikasi yang digunakan dalam proses belajar mengajar, menurut Hamalik (1994). Sejalan dengan pernyataan diatas Lautfer (1999) mengungkapkan bahwa media pembelajaran adalah salah satu perantara mengajar bagi pendidik untuk menyampaikan materi pengajaran, meningkatkan kreatifitas peserta didik dan meningkatkan perhatian peserta didik dalam proses pembelajaran.

Menurut Prasetya dkk (2021) bahwa media pembelajaran memiliki peranan penting dalam menunjang kualitas proses belajar mengajar. Sanjaya (2014) menyatakan bahwa penggunaan media yang kita kembangkan harus sesuai dengan minat dan kebutuhan peserta didik itu sendiri. Jika mengacu pada pernyataan tersebut media ini memang bisa dikatakan sesuai dengan kebutuhan dan minat peserta didik. Paparan diatas dapat disimpulkan bahwa media pembelajaran merupakan perantara dan alat komunikasi yang memiliki peranan sangat penting dalam menunjang proses kegiatan belajar mengajar dan meningkatkan minat belajar peserta didik.

Data peningkatan minat belajar diperoleh dari hasil sebelum dan sesudah menggunakan media. Hasil sebelum menggunakan media diperoleh total skor 1093,75 dengan rata-rata 54,68 dan presentase $20 \%$ dalam kategori "sangat rendah". Sedangkan hasil sesudah 
menggunakan media diperoleh total skor 1882,25 dengan rata-rata 94,11 dan presentase $100 \%$ masuk dalam kategori "sangat baik". Berdasarkan hasil tersebut dapat diketahui bahwa penggunaan media video animasi berbasis plotagon dan kinemaster dapat meningkatkan minat belajar peserta didik.

Media video animasi ini dapat meningkatkan minat belajar peserta didik karena didalam media tersebut terdapat animasi-animasi yang sangat cocok untuk para peserta didik khususnya kelas dua SD. Sejalan dengan pendapat Munir (2017) yang menyatakan bahwa media video animasi memiliki beberapa manfaat diantaranya sebagai berikut: 1) dengan menggunakan media video animasi, cara berfikir peserta didik lebih cepat dalam memahami materi yang di berikan oleh pendidik; 2) dengan menggunakan media animasi pembelajaran yang dialami akan menyengangkan; 3) peserta didik menjadi lebih aktif, kreatif, inovatif dan dapat berfikir kritis; 4) peningkatkan rasa saling pengertian dan simpati dalam kelas; 5) membuahkan perubahan signifikan tentang tingkah laku peserta didik; 6) membawa variasi bagi pengalaman belajar peserta didik.

$$
\text { Video animasi dapat }
$$
meningkatkan minat peserta didik karena warna dalam media tersebut sesuai dengan karakteristik peserta didik kelas II SD. Menurut Sudarma dkk (2015) bahwa penggunaan warna yang konsisten, serta sesuai dengan realitas yang akan menambah pengetahuan siswa itu sendiri terkait lingungkannya. Selain itu warna yang digunakan dalam suatu media memiliki dampak besar pada pemikiran serta ketertarikan peserta didik untuk belajar. Menurut Wahyudi (2019) ciri desain yang baik seperti dapat menarik perhatian siswa, pesan mudah dipahami dan dimengerti, informasi pesan dilengkapi dengan informasi visual serta dapat mengangkat intisari pesan di dalamnya.

\section{Kesimpulan}

Berdasarkan proses pengembangan media dan uji coba terhadap media video animasi berbasis Plotagon dan Kinemaster dalam mengembangakan minat belajar peserta didik kelas II SD Negeri 3 Babadan dapat disimpulkan bahwa media video animasi berbasis Plotagon dan Kinemaster dikatakan valid digunakan dalam pembelajaran tematik. Hal ini dapat dibuktikan dari hasil penilaian ahli materi dan ahli media mendapatkan presentase 100\%. Dapat diartikan bahwa media video animasi pembelajaran berbasis Plotagon dan Kinemaster dalam kategori "Sangat Baik" dan "Tidak Revisi" dapat diterapkan.

Media video animasi berbasis Plotagon dan Kinemaster dikatakan layak digunakan dalam pembelajaran tematik. Hal ini dapat dibuktikan dari hasil penilaian pengisian angket minat belajar, angket keterbacaan dan kemenarikan oleh peserta didik. Dapat disimpulkan bahwa media video animasi pembelajaran berbasis Plotagon dan Kinemaster "Sangat Baik dan Sangat Layak" digunakan.

Terdapat peningkatan minat belajar pada siswa kelas II di SD Negeri 3 Babadan, hal ini dibuktikan dengan perolehan skor dari kelompok kecil sebelum menggunakan media animasi masuk kategori "Sedang" dengan presentase $63 \%$ meningkat menjadi $100 \%$ dengan kategori "Tinggi". Kelompok terbatas sebelum menggunakan media animasi masuk 
kategori "Rendah" dengan presentase $53 \%$ menjadi $100 \%$ dengan kategori "Tinggi".

\section{DAFTAR PUSTAKA}

Arsyad, A. 2013. Media Pembelajaran. Jakarta: PT RajaGrafindo Persada.

Daryanto. 2010. Media Pembelajaran. Yogyakarta: Gaya Media.

Hamalik, O. 1994. Media Pendidikan. Bandung: Citra Adtya Bakti.

Kemendikbud. 2020.

https://www.kemdikbud.go.id/ main/blog/2020/05/kemendik bud-terbitkan-pedomanpenyelenggaraan-belajardari-rumah (Online) diakses pada tanggal 30-7- 2021

Munir. 2017. Multimedia dan Konsep Aplikasi dalam Pendidikan. Bandung: Alfabeta

Permatasari, dkk. 2019. Pengembangan Media Pembelajaran Video Animasi Hand Move dengan Konteks Lingkungan pada Mapel IPS. https://www.ejournal.radenint an.ac.id.pdf. (Online) diakses pada tanggal 27-10-2020 Pukul 19.50 Vol. 6 No. 1

Sanjaya, W. 2006. Strategi Pembelajaran Berorientasi Standar Proses Pendidikan. Jakarta: Kencana

Sudarma, dkk. 2015. Desain Pesan Kajian Analitis Desain Visual Teks Dan Image. Graha IImu.

Sugiyono. 2015. Metode Penelitian Pendidikan (Pendekatan Kuantitatif, Kualitatif, dan R\&D). Bandung: Alfabeta.

Sujanto, A. 2013. Psikologi Umum. Cet. VII; Jakarta: Aksara Baru.

Tirtarahardja, U dan Sulo, L. 2014. Pengantar Pendidikan. Jakarta: Rineka Cipta

Wahyudi, N. G. (2019). Desain Pesan Pembelajaran Dalam
Meningkatkan Mutu Pembelajaran Di Era Digital. 3(1), 15-16. 